\title{
Expulsion mechanism of xylitol 5-phosphate in Streptococcus mutans
}

\author{
ANNE PIHLANTO-LEPPÄLÄ', EVA SÖDERLING' AND KAUKO $\mathbb{K}$. MÄKINEN² \\ ${ }^{1}$ Department of Biochemistry, Institute of Dentistry, Unizersity of Turku, Turku, Finland, and \\ ${ }^{2}$ School of Dentisiry, The Unizersity of Michigan, Ann Arbor, MI, USA
}

\begin{abstract}
Pihlanto-Leppälä A, Söderling E, Mäkinen KK: Expulsion mechanism of xylitol 5-phosphate in Streptococcus mutans. Scand J Dent Res 1990; 98: 112-9.

Abstract - The expulsion mechanism of xylitol 5-phosphate in Streptococcus mutans ATCC 25175 was studied using resting cells incubated in the presence of ${ }^{14} \mathrm{C}$-xylitol. The expulsion appeared to be a two-step process: xylitol 5-phosphate was first hydrolyzed to xylitol and imorganic phosphate, and the xylitol was subsequently expelled from the cells. The dephosphorylation step appeared to be energy-requiring and it was most likely associated with a phosphatase which was active on xylitol 5-phosphate. Two to three successive cultivations of the cells in the presence of $6 \%$ xylitol increased this enzyme activity 4.3 -fold. These results are in accordance with the presence of an energy-dependent xylitol 5-phosphate cycle in $S$, mutans, which is regulated by exogenous xylitol.
\end{abstract}

Key words: S. mutans; xylitol.

Eva Söderling, Institute of Dentistry, University of Turku, SF-20520 Turku, Finland.

Accepted for publication 10 September 1989.

Several clinical studies have shown that xylitol, a naturally occurring five-carbon sugar alcohol, can be used as an effective cariespreventive agent (1-4). The cariostatic and the therapeutic (4) effects of xylitol have been attributed to both microbiologic and physicochemical actions of xylitol (for reviews, see 5,6 ).

The majority of oral bacteria cannot utilize xylitol $(7,8)$ and no adaptation to use xylitol has been detected in long-term in vivo studies $(9,10)$. On the contrary, acid production and growth of most oral streptococci are inhibited by xylitol $(11,12)$. This inhibition has been attributed to the intracellular formation of xylitol 5-phosphate (xylitol 5$P)$, which is toxic to the organism, but not to humans (11, 13). Xylitol can be transported into the cells of Streptococcus mutains and $S$. sobrinus via a phosphoenolpyruvate:fructose phosphotransferase system (13).

Regulatory mechanisms for sugar transport in Gram-positive bacteria have been studied intensively during the last years (for review, see 14). Especially the components involved in the uptake of various sugars have 
received interest (14-18). Less, however, is known about the mechanisms involved in the regulation of the levels of the intracellular sugar phosphates (14). Regulation of the sugar phosphate accumulation by expulsion was first demonstrated in $S$, pyogenes (19). An expulsion mechanism based on intracellular dephosphorylation and efflux of the free sugar has also been demonstrated in Lactobacillus casei, the sugar phosphate being xylitol 5-P (20). Indirect evidence has been presented on the existence of such an efflux mechanism in some oral streptococci as well (21-23).

The aim of the present study was to verify the existence of an expulsion mechanism for xylitol 5-P in S. mutans 25175 and to study the nature and the number of steps as well as the energy dependence of the expulsion system.

\section{Material and methods}

\section{GULTIVATION OF BACTERIA}

S. mutans ATCC 25175 cells were cultured in a medium containing $5 \mathrm{~g}$ trypticase, $5 \mathrm{~g}$ yeast extract, $5 \mathrm{~g} \quad \mathrm{~K}_{2} \mathrm{HPO}_{4 \mathrm{~g}} 4 \mathrm{~g}$ glucose, $80 \mathrm{mg}$ $\mathrm{MgSO}_{4} \cdot 7 \mathrm{H}_{2} \mathrm{O}, 4 \mathrm{mg}$ FeSO $47 \mathrm{H}_{2} \mathrm{O}, 2 \mathrm{mg}$ $\mathrm{MnCl}_{2} \cdot 4 \mathrm{H}_{2} \mathrm{O}$ and $5 \mathrm{mi}$ Tween- 80 in 1 liger of distilled water. The $\mathrm{pH}$ of the medium was adjusted to 7.2 and the medium was autoclaved for $10 \mathrm{~min}$ at $120^{\circ} \mathrm{C}$. The bacteria were pregrown overnight at $37^{\circ} \mathrm{C}$ in the basal medium followed by one culitivation in the same medium $(8 h)$. The growth was followed by measuring the turbidity with a Klett-Summerson colorimeter (filter 62).

For preparation of xylitol-cultured cells, the basal medium was supplemented with xylitol. The concentrated xylitol solution was sterilized by filtration through a Millipore filter (Millex HA 0.45 $\mu \mathrm{m})$ and added aseptically to the medium at the appropriate concentration. The cells obtained after two to three successive cultivations ( $8 \mathrm{~h}$ each) were called "xylitol-cultured cellis". Between each cultivation the cells (collected by centrifugation) were stored as a pellet (overnight at $8^{\circ} \mathrm{C}$ ) in the presence of $6 \%$ xylitol. Control cells were cultivated successively in the basal medium without added xylitol.

\section{XYLITOL 5-P EXPULSION}

The cells for expulsion studies were harvested from cultures at the end of the mid-log phase of growth. $\left(12000 \times g, 4^{\circ} \mathrm{C}, 10 \mathrm{~min}\right)$ and washed twice with $50 \mathrm{mM}$ sodium phosphate buffer ( $\mathrm{pH} 7.0$ ) containing $4 \mathrm{mM} \mathrm{MgCl}$. The cells were finally suspended in the above buffer to a final concentration of $1.0-1.5 \mathrm{mg}$ (dry weight) per $\mathrm{ml}$. The suspensions were preincubated for $10 \mathrm{~min}$ at $37^{\circ} \mathrm{C}$ using agitation whereafter [ $\left.\mathrm{U}^{\mathrm{B}}{ }^{4} \mathrm{C}\right]$ ]-xylitol (Amersham, Buckinghamshire, England) was added to the mix tures. (final specific activity $0.1 \mathrm{mCi} / \mathrm{mm}$ mol, total concentration of xylitol $1 \mathrm{mM}$ ). After $15 \mathrm{~min}$ incubation at $37^{\circ} \mathrm{Cl}$ the mixtures were chilled to $0^{\circ} \mathrm{C}$ and the resulting "preloaded cells" were harvested $\left(12000 \times \mathrm{g}, 4^{\circ} \mathrm{C}, 2 \mathrm{~min}\right)$. The cell pellets were resuspended by rapid wortexing in the above buffer $\left(37^{\circ} \mathrm{C}\right)$.

To study the expulsion mechanism the following compounds were added to the above cell suspensions containing preloaded cells: D-glucose, Dfructose, xylitol, L-arginine, $\mathrm{NaF}_{\text {, iodoacetic acid }}$ (IAA), and $\mathrm{Na}$-arsenate. The final concentrations are given in figure legends. In some experiments a preincubation time of 5 min was used before triggering the expulsion by the addition of glucose. All incubations were performed at $37^{\circ} \mathrm{C}$.

The total label of the cellis and the levels of intracellular ${ }^{14} \mathrm{G}$-xylitol and ${ }^{14} \mathrm{G}$-xylitol 5-P were determined from duplicate samples withdrawn at proper time intervals from the cell suspensions. For the determination of total label (sample size $0.4 \mathrm{ml}$ ) the cells were collected on membrane filters (Millex HA $0.45 \mu \mathrm{m}$ ). The filters were rinsed twice with $4 \mathrm{ml} 0.9 \% \mathrm{NaCl}$ and transferred to scintillation vials. Five $\mathrm{ml}$ of scintillation cocktail (ACS, Amersham) was added to each vial and the radioactivity of the cells was determined with a LKB 1210 Ultrobeta Liquid Scintillation Counter (L.KB-Wallac, Turku, Finland). For the determination of intracellular ${ }^{14} \mathrm{C}$-xylitol and ${ }^{14} \mathrm{C}$-xylitol 5-P the cells (sample size $0.4 \mathrm{ml}$ ) were collected by centrifugation $\left(12000 \times g_{3} 4^{\circ} \mathrm{C}, 2 \mathrm{~min}\right)$. Each cell pellet was treated for $10 \mathrm{~min}$ in $3 \mathrm{ml}$ boiling water. The resulting suspensions were cleared by centrifugation $\left(12000 \times \mathrm{g}, 4^{\circ} \mathrm{C}, 10 \mathrm{~min}\right)$. The supernatants were freeze-dried and the residues were finally dissolved in $0.5 \mathrm{ml}$ of distilled water. ${ }^{14} \mathrm{C}-$ $\mathrm{X} y$ litol and ${ }^{14} \mathrm{C}$-xylitol $5-\mathrm{P}$ in the solutions were determined by ion exchange chromatography on an AG 1-X2 resin (50-100 mesh, BioRad Labora- 
tories, Richmond, CA) as previously described (24).

\section{PHOSPHATASE ACTIVITY OF CELL EXTRACTS}

The phosphatase activities were determined from cell extracts of $S$. mutans grown in the basal medium only, and from xylitol-cultured cells.

The cell extracts were prepared as follows. The cells were harvested from the late logarithmic growth phase by centrifugation and washed twice with $50 \mathrm{ml}$ of $0.02 \mathrm{M}$ [2-(N-morpholino)ethanesulfonic acid]-buffer (MES) $(\mathrm{pH} 6.2)$ containing $5 \mathrm{mM} \mathrm{MgCl}_{2}$ and $10 \mathrm{mM}$ 2-mercaptoethanol, to remove phosphate. The cells were then suspended to the above MES-buffer to a final concentration of $0.25 \mathrm{mg}$ (wet weight) of cells per $\mathrm{ml}$. The final cell-free extracts were prepared from these suspensions by treating them twice ( $6 \mathrm{~min}$ at a time) with an ultrasonic disintegrator (MSE disintegrator; amplitude 6 , end diameter of the probe $3 \mathrm{~mm}$ ) at $4^{\circ} \mathrm{C}$. The sonicates were cleared by centrifugation $\left(50000 \times g, 4^{\circ} \mathrm{C}, 30 \mathrm{~min}\right)$.

The phosphatase activity of the resulting supernatants was studied using the following substrates: D-glucose 1-phosphate $(\mathbf{P}), \mathrm{D}$-glucose 6-P, D-mannitol I-P, D-ribose 5-P, D-ribulose 5-P, D-fructose 6-P, D-fructose 1,6-diP, D-galactose 6-P, glucosamine 6-P, xylitol 5-P adenosine triphosphate (ATP) as sodium salt, phosphoenolpyruvic acid (PEP), D-sorbitol 6-P and 6-P-gluconic acid and 3-Pglyceric acid. Xylitol 5-P was synthesized from the corresponding ketosugar by a sodium borohydride reduction procedure described by Marzief \& Metzenburg (25) as modified by London \& Hausman (26). The enzyme assay was based on the colorimetric method of Horder (27). The reaction time was $60 \mathrm{~min}$ at $37^{\circ} \mathrm{C}$, under which conditions the enzyme reaction was linear.

The protein concentrations of the cell extracts were measured with the Folin method (28),

\section{Results}

\section{ENERGY DEPENDENCE OF XYLITOL 5-P EXPULSION}

The presence of D-glucose and D-fructose ( 5 mM) increased the rate of expulsion of the label from $S$, mutans preloaded with ${ }^{14} \mathrm{C}$-xylitol 5-P (Fig. 1), but the presence of $5 \mathrm{mM}$ xylitol had no effect on the rate of expulsion (Fig. 1). The expulsion of the label in the presence of $4 \mathrm{mM}$ D-glucose was inhibited by inhibitors of glycolysis, IAA (inhibitor of glyceraldehyde 3-phosphate dehydrogenase) and $\mathrm{NaF}$ (inhibitor of enolase) $(10 \mathrm{mM}$, Fig. 2). When $2 \mathrm{mM} \mathrm{L}$-arginine (a non-glycolytic source of ATP) was added to the incubation mixtures simultaneously with IAA (not shown) or NaF (Fig. 2), the inhibitory effect was abolished. L-Arginine alone, without Dglucose, did not induce expulsion of preaccumulated xylitol 5-P. Thus the expulsion of xylitol 5-P appeared to be an energy-dependent process (involving possibly ATP).

\section{NUMBER OF STEPS INVOLVED IN THE EXPULSION OF XYLITOL 5-P}

Two mechanisms may account for the expulsion of xylitol 5-P by $S$. mutans: either the xylitol 5-P is dephosphorylated intracellularly followed by efflux of free xylitol (two-step mechanism) or both the dephosphorylation and efflux occur simultaneously (one-step mechanism).

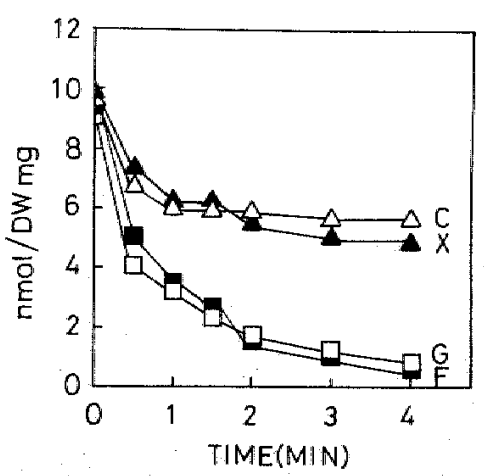

Fig. 1. Effect of D-glucose, D-fructose and xylitol on xylitol expulsion by preloaded cells of $S$. mutans, given in nmol of expelled xylitol per mg cells (dry weight). The expulsion was followed at $37^{\circ} \mathrm{C}$ in the presence of $5 \mathrm{mM} x y l i t o l(\Lambda-\Lambda), 5 \mathrm{mM}$ D. glucose $(\square-\square), 5 \mathrm{mM}$ D-fructose $(\mathbf{\square}-\mathbf{m})$, or with no additions $(\Delta-\Delta)$. 
The first set of experiments designed to reveal the connection between the dephosphorylation of xylitol 5-P and the efflux of this compound involwed $\mathrm{Na}$-arsenate, an inhibitor of intracellular dephosphorylation.

Preincubation with Na-arsenate inhibited expulsion of ${ }^{14} \mathrm{C}$-xylitol $5-\mathrm{P}$ by preloaded $S$. mutans cells (Fig. 3A). Na-arsenate did not, however, inhibit the efflux of ${ }^{14} \mathrm{C}$-xylitol, formed before the addition of the inhibitor (Fig. 3B and C). Thus enzymatic dephosphorylation of xylitol was necessary before the expulsion of xylitol 5-P could take place.

The second set of experiments was performed with cells preincubated with $10 \mathrm{mM}$ $\mathrm{NaF}$ and $5 \mathrm{mM}$ L-arginine essentially according to REIZER $e$ al. (29). Fig. 4A shows the efflux of xylitol $5-\mathrm{P}$ as triggered by 10 $\mathrm{mM} D$-glucose (control). In theory, the addition of unlabeled xylitol to this reaction mixture caused an uptake of the unlabeled xylitol and resulted in competition for efflux (29). In fact, for a high concentration $(100$

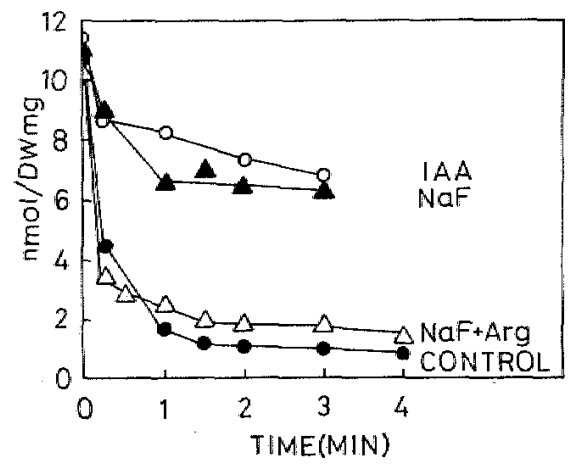

Fig. 2. Effect of IAA, NaF and L-arginine on expulsion of xylitol by preloaded cells of $S$. mutans. at $37^{\circ} \mathrm{Cl}$ given in nmol of expelled xylitol per $\mathrm{mg}$ cells (dry weight). Cells were preincubated for 5 min (at $37^{\circ} \mathrm{C}$ ) in the presence of $10 \mathrm{mM}$ IAA $(0-0), 10 \mathrm{mM} \mathrm{NaF}(\mathbf{\Delta - \Delta})$, or $10 \mathrm{mM} \mathrm{NaF}$. 2 mM L-arginine $(\Delta-\Delta)$. The control cells were preincubated without any additions (-). The expulsion was triggered by the addition of $5 \mathrm{mM}$ glucose.
mM) of external xylitol, the amount of ${ }^{14} \mathrm{C}$ xylitol within the cells was clearly higher than in the controls (Fig. 4A and D). Even a ten-fold lower external xylitol concentration $(10 \mathrm{mM})$ resulted in elevated ${ }^{14} \mathrm{C}$-xylitol levels in $S$. mutans (Fig. 4C). The external xylitol however, had no effect on the levels of intracellular ${ }^{14} \mathrm{C}$-xylitol 5-P (Fig. 4). Thus, only the efflux of ${ }^{14} \mathrm{C}$-xylitol was inhibited, not the dephosphorylation of xylitol 5-P. This result together with the $\mathrm{Na}$-arsenate experiment described abowe speaks for a two-step expulsion mechanism for xylitol 5-P: 1) enzymatic dephosphorylation of xylitol 5-P, and 2) subsequent efflux of free xylitol.

PHOSPHATASE ACTIVITY IN $S$. MUTANS CELL EXTRACTS

S. mutans cell extracts showed phosphatase activity towards phosphorylated sugars, sugar alcohols and hexonic acids. The best substrates were galactose 6-P and glucose 6-P (Fig. 5A). The following substrates examined were hydrolyzed with rates ranging from 40 to $60 \%$ as compared to galactose 6 -P: xylitol 5-P, fructose 6-P, ribose 5-P, glucosamine 6P, ATP, glucose 1-P, 3-phosphoglyceric acid, PEP, and fructose 1,6-diphosphate. The rest of the substrates mentioned above were hydrolyzed at even lower rates. Successive cultivations of the cells in the presence of $6 \%$ xylitol considerably increased the rates of hydrolysis of especially the sugar 5- and 6phosphates (Fig. 5A, 5B, and 5C). For example, three successive cultivations of $S$. mutans in the presence of $6 \%$ xylitol increased the hydrolytic activity towards galactose 6-P (3.3-fold), fructose 6-P with 6.3-fold, xylitol 5-P (4.3-fold) and ribose 5-P (7.9-fold) (Fig. 5). The enzyme activities towards ATP, PEP, 3-phosphoglyceric acid, and fructose 1,6-diphosphate were, however, affected to a small extent by the successive cultivations in the presence of xylitol. 


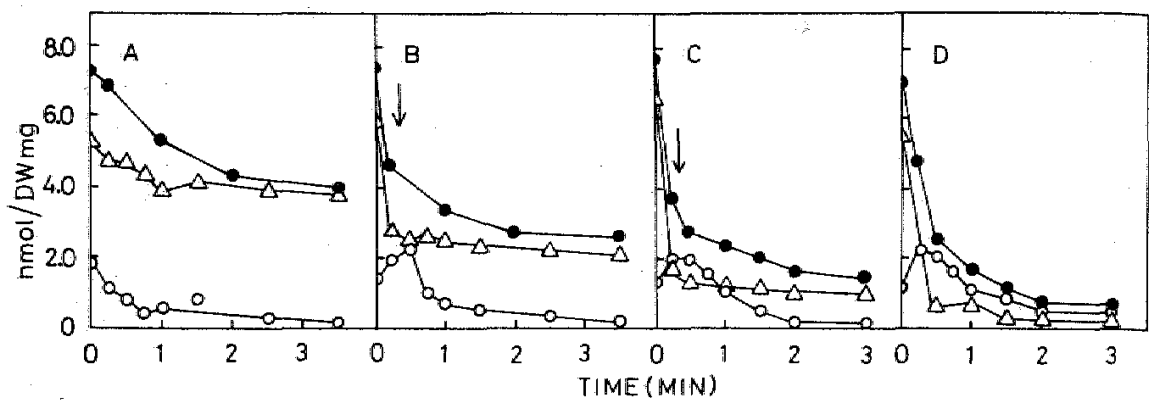

Fig. 3. Effect of $10 \mathrm{mM}$ sodium arsenate on the expulsion of xylitol by preloaded cells of $S$. mutans at $37^{\circ} \mathrm{C}$. Expulsion was elicited by addition $5 \mathrm{mM} \mathrm{D}$-glucose. Na-arsenate was added (A) prior to Dglucose addition (preincubation at $37^{\circ} \mathrm{C} 5 \mathrm{~min}$ ), (B) $10 \mathrm{~s}$, or (G) $20 \mathrm{~s}$ after D-glucose addition (arrow). $\mathrm{D}$, control without any additions. Duplicate samples were collected for the determination of total label (-),${ }^{14} \mathrm{C}$-xylitol (O-O), and ${ }^{14} \mathrm{C}-\mathrm{xylitol}$ 5-P $(\Delta-\Delta)$.

\section{Discussion}

The key compound in the grawth inhibition of streptococci by xylitol appears to be xylitol 5-P. Different streptococci, however, seem to differ in their handling of the toxic xylitol metabolite. Successive cultivations of $S$. mutans LG-1 led to a selection of "xylitol- resistant" cells devoid of the PEP:fructose phosphotransferase needed for the uptake of xylitol (30). Successive cultivations of $S$. sobri$n u s$ in the presence of xylitol also led to a decrease in the uptake of xylitol. This phenomenon was, however, reversible and should thus not involve selection of xylitolresistant cells (31). Evidence on the existence

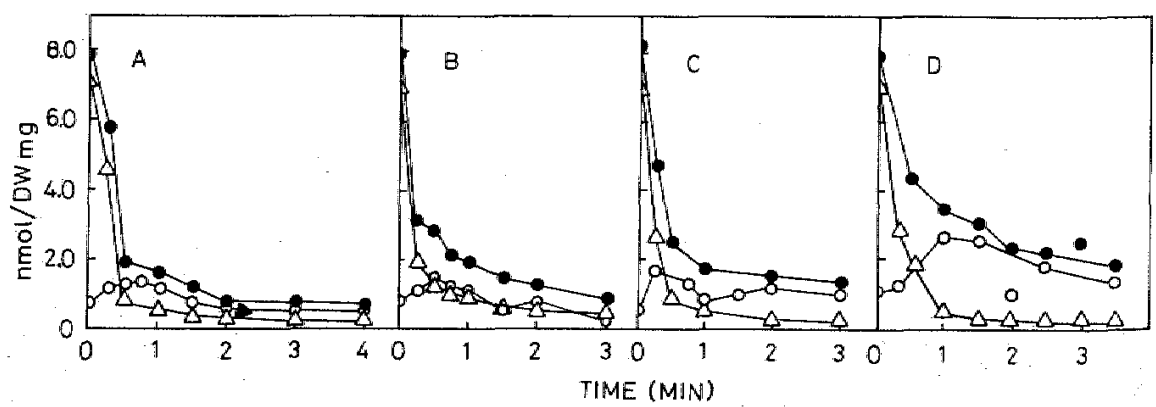

Fig. 4. Intracellular content of ${ }^{14} \mathrm{C}$-xylitol, ${ }^{14} \mathrm{C}$-xylitol 5-P and total label (xylitol plus xylitol 5-P) of cells during expulsion process. Preloaded $S$. mutans cells were suspended in buffer $\left(37^{\circ} \mathrm{C}\right)$ containing (A) $10 \mathrm{mM} \mathrm{NaF}$ and $5 \mathrm{mM} \mathrm{L}$-arginine, (B) $10 \mathrm{mM} \mathrm{NaF}, 5 \mathrm{mM}$.L-arginine and $1 \mathrm{mM}$ unlabeled xylitol, (C) $10 \mathrm{mM} \mathrm{NaF}, 5 \mathrm{mM}$ arginine and $10 \mathrm{mM}$ unlabeled xylitol, or (D) $10 \mathrm{mM} \mathrm{NaF}, 5 \mathrm{mM} \mathrm{L}$ arginine and $100 \mathrm{mM}$ unlabeled xylitol. Mixtures were preincubated for $5 \mathrm{~min}$. Expulsion was them elicited by addition of $10 \mathrm{mM}$ D-glucose. Duplicate samples were collected for determination of total label $(-0),{ }^{14} \mathrm{C}$-xylitol $(\mathrm{O}-\mathrm{O})$, and ${ }^{14} \mathrm{C}$-xylitol 5-P $(\Delta-\Delta)$. Results are given in nmol of labeled compound per dry weight of bacteria (in $\mathrm{mg}$ ). 


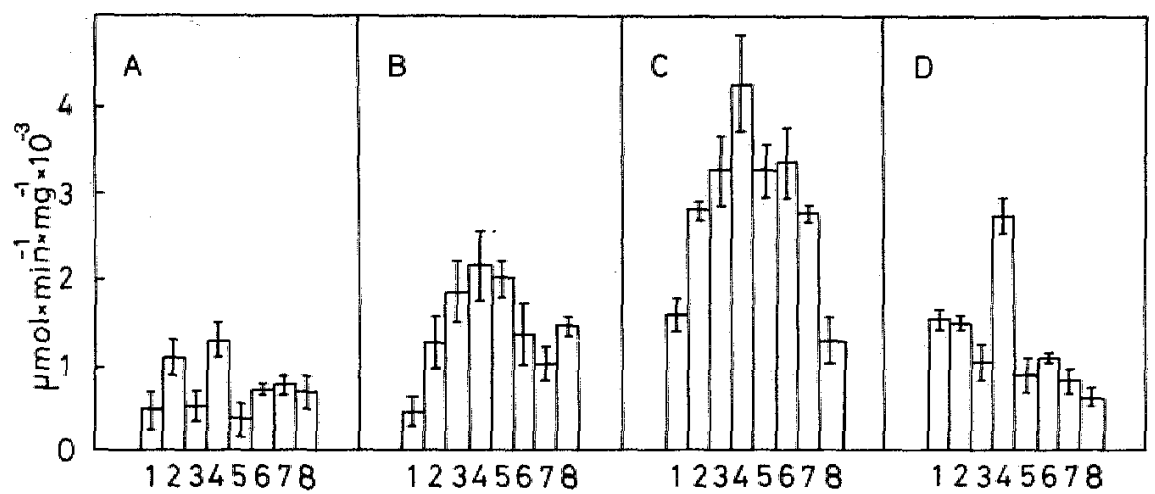

Fig. 5. Phosphatase activity of $S$. mutans cell extracts. Extracts of control cells grown in basal medium (A), or of cells obtained after two (B) or three (C) successive xylitol $(6 \%)$ cultivations, or after three xylitol and one basal medium cultivation (D), were used in experiments. Phosphatase activities were determined using following substrates: 1: glucose 1-P. 2: glucose 6-P. 3: fructose 6-P. 4: galactose 6-P. 5: ribose 5-P. 6: xylitol 5-P. 7: glucosamine 6-P. 8: ATP. Values shown are means \pm SD $(n=3-5)$ of specific enzyme activities. Enzyme assays were performed in $0.1 \mathrm{MES}$ buffer, $\mathrm{pH} 6.0$, containing $5 \mathrm{mM} \mathrm{MgSO}$, final substrate concentration being $10 \mathrm{mM}$ (for ATP $5 \mathrm{mM}$ ).

of a futile, energy-demanding xylitol 5-P cycle in $S$. mutans has also been presented (21-23). The intracellular xylitol 5-P has been proposed to inhibit glycolysis (32), but it could also act as an intracellular regulator. In fact, the level of xylitol 5-P in growing cells of $S$. mutans 25175 has been reported to be high (22).

The present study focused on the expulsion of xylitol 5-P by $S$. mutans 25175. The results speak for a two-step process in which xylitol 5-P is first dephosphorylated with subsequent expulsion of free sylitol. Such a mechanism has been demonstrated to be responsible for the expulsion of methyl $\beta$-D-D thiogalactoside phosphate (TMG-P) by $S$. pyogenes and xylitol 5-P by $L$. casei $(20,29$, 33). Expulsion of sugar phosphates appears to be one of the diverse mechanisms grampositive bacteria use to regulate sugar accumulation $(14,34)$.

The energy dependency of the expulsion of xylitol 5-P by S. mutans 25175 was demonstrated by the experiments showing that rapmid expulsion of xylitol was possible only in the presence of a metabolizable substrate (Dglucose, D-fructose) but not a non-metabolizable one (xylitol). Furthermore, inhibitors of glycolysis inhibited the expulsion. Our experiments do not allow us to conclude which one of the two expulsion steps needed energy. In $S$. pyogenes the energy may be needed for the activation of the dephosphorylation mechanism (29). The results of the present experiments involving L-arginine, D-glucose, and glycolysis inhibitors resembled those reported for the expulsion of TMG-P by $S$. pyogenes: the results indicate that both ATP and a glycolytic intermediate are required for optimal dephosphorylation (29). In S. pyogenes phosphorylation of a protein is also involved in the expulsion process (29).

The cell extracts of $S$. mutans 25175 showed phosphatase activity with a broad substrate specificity. Hexose 6-phosphohydrolases have been detected in and purified from a variety of microorganisms (35-38). In $L$. casei, an ind wcible, membrane-regulated xylitol 5-P phosphatase has been characterized (38). The exact physiologic role of these phospha- 
tases is largely unknown. They may, however, detoxify certain sugar phosphates and regulate the concentrations of glycolytic in termediates. It has also been suggested that the sugar-phosphate hydrolase of $S$. lactis is involved in the expulsion of sugar phosphates (37). In the present study, successive cultivations of $S$, mutans in the presence of xylitol clearly increased the level of the five- and six-carbon sugar-P hydrolase(s), while the activities towards PEP and ATP, for example, were less affected. These reactions were reversible. This argues for the participation of an inducible sugar phosphatase in the regulation of the intracellular xylitol 5-P level in S. mutans 25175. Also our previous study indicated that the rate of expulsion of xylitol 5-P by $S$. mutans 25175 was increased by successive xylitol cultivations $(20)$. Thus it appears that the first step of the expulsion of xylitol 5-P is its hydrolysis to xylitol by an inducible sugar phosphatase. The involvement of a phosphatase in the first efflux step was also suggested by the Na-arsenate inhibition experiments. The regulation of the efficiency of the xylitol 5-P efflux appeared to be connected to this step. The broad substrate specificity of the phosphatase indicates that the enzyme may function in several other dephosphorylation reactions as well.

As a conclusion, the present study suggests that the efflux of xylitol 5-P in $S$. mutans 25175 is a two-step, energy (ATP)-demanding process, the first step being the hydrolysis of the phosphate by an inducible sugar (C5 and $C 6$ ) phosphatase.

\section{References}

1. Sceeninin A, Mäkrnen KK, eds. Turku sugar studies. Acta Odontol Sicand 1975; 70: Suppl 33: $1-350$.

2. SGHernin A, Bánóczy J. Xylitol and caries: the collaborative WHO oral disease preventive programme in Hungary. Int Dent 71985 ; 35: $50-7$.

3. Kandelman D, GaGNoN G. Clinical results after 12 months from a study of the incidence and progression of dental caries in relation to consumption of chewing-gum containing xylitol in school preventive programs. 7 Dent Reir 1987; 66: 1407-11.

4. Isokangas P, Alanen P, Tiekso J, Märinen $\mathrm{KK}$. Xylitol chewing gum in caries preverntion: a field study in children at caries-active ages. $7 A D A$ 1988; 117: 315-20.

5. MäkINEN KK. New biochemical aspects of sweeteners. Int Dent $f$ 1985; 35: 23-35.

6. Märnnen KK, Isokangas P. Relationship between carbohydrate sweeteners and oral diseases. Proc Food Nutr Sci 1988; 12: 73-109.

7. Enwardoson S, Berkhed D, Mejare B. Acid production from lycasin, maltitol, sorbitol and xylitol by oral streptococci and lactobacilli. Acta Odontol Scand 1977; 35: 257-63.

8. Havenaar R, Huis In't Veld JHJ, Backer Dirks $O$, de StoppelaAr JD. Some bacteriological aspects of sugar substitutes. In: GuGGENHEM, ed. Health and sugar substitutes. Basel: Karger, 1979; 192-8.

9. MäKInEN KK, VIRTANEN KK. Effect of 4.5year use of xylitol and sorbitol on plaque. $\mathcal{J}$ Denl Res 1978; 57: 441-6.

10. MÄKinen KK, SöDERLING E, HämÄLÄINEN $M$, ANTONEn P. Effect of long-term use of xylitol on dental plaque. Proc Finn Dent Soc 1985; 81: 28-35.

11. Assev S, Vegarud G, Rölla G. Growth inhibition of Streptococcus mutans strain OZM 176 by xylitol. Acta Pathol Microbiol Immunol Scand Sect B 1980; 88: 61-3.

12. Vabeboncoeur C, Trahan L, Mouton G, MAYrand D. Effect of xylitiol on the growth and glycolysis of acidogenic oral bacteria. $f$ Dent Ries 1983; 62: 882-4.

13. Trahan L, Bareil M, Gavthier L, VadeBoncoevr C. Transport and phosphorylation of xylitol by a fructose phosphotransferase system in Streptococcus mutans. Caries Res 1985; 19: $53-63$.

14. Reizer J, Peterkofsky A. Regulatory mechanisms for sugar transport in gram-positive bacteria. In: Reizer J, PETERKofsky A, eds.; Sugar transport and metabolism in Gram-positive bacteria. Chichester: Ellis Horwood, 1987.

15. Gauthink L, Maxrand D, Vadeboncolur $C$. Isolation of a nowel protein involved in the transport of fructose by an inducible phosphoenolpyruwate fructose phosphotransferase sys- 
tem in Streptococcus mutans. 7 Bacteriol 1984; 160: $755-63$.

16. VAdeboncoeur G. Structure and properties of the phosphocnolpyruwate: glucose phosphotransferase system of oral streptocacci. Can 7 Microbiol 1984; 30: 495-502.

17. Vabeboncoeur G, Thibault L, Neron S, Halvorson $\mathbb{H}$, Hamilton IR. Effect of growth conditions on levels of components of the phosphoenolpyruvate:sugar phosphotransfierase system in Streptococcus mutans and Streptacoccus sobrinus grown in cotitinwous culture. 7 Bacteriol 1987; 169: 5686-91.

18. Rodrique L, Lacoste L, Trahan L, VadeBoncOEUR C. Effect of nutritional constraints on the biosynthesis of the components of the phosphoenolpyruvate:sugar phosphotransferase system in a fresh isolate of Streptococcus mutans. Infect hnmun 1988; 2: 518-22.

19. Reizer J, Panos C. Regulation of $\beta$-galactoside phosphate accumulation in Streptococcus pyogenes by an expulsion mechanism. Proc Natl Acad Sci USA 1980; 77: 5497-5501.

20. Hausman SZ, Thompson J, London J. Futile xylitol cycle in Lactobacillus casei. $\mathcal{I}$ Bacteriol 1984; 160: 211-5.

21. Ten Brink B, Beckers HJA. Does xylitol inhibit growth and acid production of Streptococcus mutans by the introduction of a PEPconsuming futile cycle? $\mathcal{J}$ Dent Res (Spec Issue) 1985; 64: 194 (only).

22. Söderling E, Pihlanto-Leppälä A. Uptake

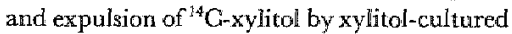
Streptococcus mutans ATCC 25175 in vitro. Scand 7 Dent Res: in press.

23. Assev $S$, Rölla G. Further studies on growth inhibition of Streptococcus mutans OMZ 176 by xylitol. Acia Pathol Microbial-Immunol Scand 1986; Sect B, 94: 97-102.

24. Kundig W, Roseman S. Sugar transport II Characterization of constitutive membramebound enzymes II of the Escherichia coli phosphotransferase system. I Biol Chem 1971; 246: $1407-18$

25. Marzluf GA, Metzenbergi RI. A simplified preparation of the unusual disaccharides, 3ketosucrose and allosucrose. Anal Biachem 1965; 13: 168-70.

26. London J, Hausman S. Xylitol-mediated tran- sient inhibition of ribitol entilization by Lactobacillus casei. 7 Bacteriol 1982; 150: 756-61.

27. Horder M Colorimetric determination of orthophosphate in the assay of inorganic pyrophosphatase activity. Anal Biochem 1972; 49: $37-47$.

28. Lowry OH, Rosebrovgh MJ, Farr AL, Randali RJ. Protein measurement with the Folin phenol reagent. 7 Biol Chem 1951; 193: $265-75$.

29. Reizer J, Novotny MJ, Panos C, Saier JR $\mathrm{MH}$. Mechanism of inducer expulsion in Streptococcus pyogenes: a two-step process activated by ATP $\mathcal{J}$ Bacterial 1983; 156: 354-61.

30. Gauthier L, Vadebongoeur G, Mayrand D. Loss of sensitivity to xylitol by Streptococcus mutans LG-1. Caries Res 1984; 18: $289-95$.

31. Pihlanto-Leppë̈lä A, Söderling E, MäKJNEN KK. Uptake of ${ }^{14} \mathrm{C}$-xylitol by xylitol-cultured Streptocaccus sobrinus ATCC 27352 and Streptococcus mitis ATCC 36249 in witro, manuscript: Proc Finn Dent Sac: submitted.

32. Ten BRink B, Beckers HJA. Does xylitol inhibit growth and acid production of Steptococcus matans by the introduction of the PEPconsuming futile cycle? I Dent Res (Spec Issue) 1985; 64: 194 (only).

33. Sutrina SL, Reizer J, Sater JR MH. Induced expulsion in efflux reaction. $\bar{J}$ Bacteriol 1988; 170: 1874-7.

34. Reizer J, Deutscher J, Sutruna S, ThompSON J, SaAER JR MiH. Sugar accumulation in Gram positive bacteria: exclusion and expulsion mechanisms. TIBS 1985; January: 32-5.

35. LeE Y, Soworinos JR, ERwin MJ. Sugar phosphate phosphohydrolase. I. Substrate specificity, intracellular localization, and purification from Neisseria meningitidis. $7 \mathrm{Biol}$ Chem 1967; 242. 2264-71.

36. Kier LD, Weppelman R, Ames BN. Resolution and purification of three periplasmic phosphatases of Salmowella typhimurium. $\mathcal{J}$ Bacteriol 1977; 130: 399-410.

37. Thompson J, Chassy BM. Intracellular hexase-6-phosphate: phosphohydrolase from Streptococcus lactis: purification, properties and function. J Bacteriol 1983; 156: 70-80.

38. London Jy Hausman SZ, Thompson J. Characterization of a membrane-regulated sugar phosphate phsophohydrolase from. Lactobacillus casei. $\mathcal{J}$ Bacteriol 1985; 163: 951-6. 
This document is a scanned copy of a printed document. No warranty is given about the accuracy of the copy. Users should refer to the original published version of the material. 